UDC 658.3

O.V. TARASEVICH, Cand. of Economic Sciences, associate professor,

Head of the Department of Economic and Legal Problems of City Studies Institute of Economic and Legal Researches of the NAS of Ukraine, Kyiv, Ukraine (iD) orcid.org/0000-0002-6016-3608

G.G. NESTEROV, junior researcher, Department of Economic and Legal Problems of City Studies Institute of Economic and Legal Researches of the NAS of Ukraine, Kyiv, Ukraine (iD) orcid.org/0000-0003-3067-1377

\title{
MANAGEMENT OF MUNICIPAL ENTERPRISES OF THE CITY ON THE BASIS OF IMPROVEMENT OF THE PERSONNEL MANAGEMENT STRUCTURE
}

Keywords: management, personnel, communal enterprises, organizational structure, territorial community.
(C) O.V. TARASEVICH, G.G. NESTEROV , 2018
The article substantiates the main directions of improvement of the personnel management structure of communal enterprises as a strategic imperative for the development of a city management system. The influence of improvement of the personnel management structure on the development of the management system of municipal enterprises of the city is analyzed. The conclusion is made on the need to improve the efficiency of utility companies in order to bring them to European standards based on the improvement of the personnel management structure.

Introduction. Management of utility companies is a dominant factor in solving the problems of organizing urban living environment. The very existence of communal enterprises is due to the presence of common interests in the cities, the collective needs of the territorial community, whose satisfaction relies on local self-government bodies. The communal sector of the economy is created in the process of conducting a city economy and serves as a function of providing the territorial community with public goods. Management of communal enterprises is carried out through the system of organizational and economic authority of territorial communities and local self-government bodies in relation to economic entities of the municipal sector of the economy. Local self-government bodies create and maintain communal property objects that guarantee the provision of services, participate in the establishment of industrial enterprises, regulate relations with consumers, and provide a system of information. Local governments are responsible for the consequences of the activities of economic entities of the communal sector of the economy, on the grounds, within the limits and in accordance with the procedure established by law (Part 5 of Article 24 of the Commercial Code of Ukraine) [1]. Therefore, the decision of issues of improvement of management of municipal enterprises of the city on the basis of improvement of the personnel management structure becomes acute in the current conditions of development of Ukrainian cities.

Analysis of recent research and publications. The problems of improving the management of communal enterprises are taken up by such Ukrainian scientists as I. Zablodskaya, G. Monastyrsky, I. Zatatrina, T. Lebed, S. Noskov, M. Norekyan, S. Naiden [2-7]. However, in today's conditions of 


\begin{tabular}{|l|}
\hline \multicolumn{1}{|c|}{ City management system } \\
\hline $\begin{array}{l}\text { Strategic concept of city development: } \\
\text { - activities of utility companies } \\
\text { • operational and current plans and forecasts } \\
\text { - a business plan }\end{array}$ \\
$\begin{array}{l}\text { Assessment of the conditions of activity and economic } \\
\text { opportunities of communal enterprises: } \\
\text { • material resources } \\
\text { • workforce } \\
\text { • financial resources } \\
\text { • sales market opportunities } \\
\text { • competitors } \\
\text { • conpliers } \\
\text { • debtors }\end{array}$ \\
\hline $\begin{array}{l}\text { Organizational model of financial and economic } \\
\text { activity of communal enterprises }\end{array}$ \\
\hline $\begin{array}{l}\text { Organizational structure of personnel management } \\
\text { of municip al enterprises of the city }\end{array}$ \\
\hline
\end{tabular}

The scheme of construction of the organizational structure of personnel management of municipal enterprises of the city

economic development of Ukrainian cities, development of new scientific approaches to management of municipal enterprises of the city is necessary on the basis of improvement of the personnel management structure. Thus, Prof. G.L. Monastyrsky points out the following factors that, in his opinion, make sense the feasibility of the existence and improvement of management of utility companies: the need for uninterrupted guaranteed quality and minimum quality standards for the provision of vital services; local (local) monopoly of enterprises, by virtue of which the local self-government body does not want to be dependent on private subjects; the desire to ensure social justice and to prevent discrimination of consumers of services (by micro-districts of residence, categories of consumers); the ability of the municipal government to influence prices and tariffs [2].

The purpose of the article is to substantiate the need to improve the personnel management structure as the basis for the development of municipal enterprises of Ukrainian cities.

Research results. The communal sector of the economy is created in the process of conducting a city economy and serves as a function of providing the territorial community with public goods.

Communal enterprises are characterized by belonging to a certain territorial community, close interconnection with the provision of socio-economic needs of its members, the use of local resources, the special nature of products and services, and specific ways of providing them to the population. They are created by local governments in an orderly manner on the basis of a separate part of communal property.

In today's conditions of urban development, an important role is given to scientifically based definition of management functions and quantity norms as part of the overall process of forming the organizational and management structure of communal enterprises, defining a system of management goals that determine the structure and content of the functions of the management apparatus of municipal enterprises of the city (Figure).

The scheme of construction of the organizational structure of personnel management of municipal enterprises of the city

The effectiveness of building an organizational management structure is not evaluated by only one indicator. On the one hand, it is necessary to take into account the extent to which the structure ensures achievement of the results of the communal enterprise corresponding to the objectives set for it in the financial and economic activity, on the other hand - how its internal structure and processes of functioning are adequate to the objective requirements to their content and properties.

The ultimate criterion of efficiency when comparing different variants of organizational structures of management is the most complete and steady achievement of the goals of financial and economic activity of the enterprise. Therefore, it is advisable to use a set of regulatory characteristics of the control apparatus: its performance in the processing of information, the efficiency of making managerial decisions, the reliability of the management apparatus, expressed in the implementation of decisions within the established time frame and resources, adaptability and flexibility, characterized by timely detection of problems and the corresponding reorientation of work.

The criterion of the efficiency of the management structure is not reduced to reducing the number of employees of the enterprise management apparatus. It is a criterion for cost-effectiveness, according to which the results of management costs should be maximized.

The process of formation of the organizational structure of management of the communal enterprise includes the formulation of goals and ob- 
jectives, the definition of the composition and location of the units, their resource support, the development of regulatory procedures, documents, regulations and regulates the forms, methods, processes carried out in the system of management of financial and economic activities of the enterprise. The process involves three stages: 1) the formation of a general structural scheme of the control apparatus; 2) development of the composition of the main units and the links between them; 3 ) the regulation of the organizational structure of the management of the communal enterprise.

Formation of the general structural scheme in all cases is of fundamental importance, since it defines the main characteristics of the utility company, as well as the directions on which the design of the management structure of it is carried out.

The development of the structure of the main units and the links between them is that the implementation of organizational decisions is expected not only in the whole on the large linear-functional and program-target blocks, but also in the independent (basic) units of the management apparatus, the distribution of specific tasks between them and building internal organizational relationships. Under the basic units are structural units with their own internal structures, which are subject to the action of linear functional and programmatic subsystems.

The regulation of the organizational structure of management involves the development of quantitative characteristics of the links management apparatus and management procedures. It includes: the definition of the composition of the internal elements of the basic units, the definition of the number of units, the complexity of the main types of work and the qualification of the performers, the division of tasks and work between the specific performers, the establishment of responsibility for their implementation, the development of procedures for the implementation of management work in subdivisions, the development of the order of interaction units at carrying out of interrelated complexes of works, calculations of expenses for management and indicators of efficiency of control apparatus in conditions of designed organizational management structure.

The design of the organizational structure of management by utilities is carried out by the following methods: analogies, expert-analytical, structuring of objectives, organizational modeling.

The analogy method concerns the application of organizational forms and management methods that have proved to be true in enterprises with similar organizational characteristics in relation to the enterprise for which the organizational structure of management is projected. This method involves the development of a typical governance structure of a communal enterprise, the definition of boundaries and the conditions for their application.

The expert-analytical method consists in the survey and analytical study of the project organizational structure of management by qualified experts - experts. Experts should identify specific features, problems in the work of the control apparatus, develop rational recommendations for its improvement and increase its efficiency.

The method of structuring the goals involves the development of a system of management objectives of a utility, including their quantitative and qualitative characteristics, and a subsequent analysis of management structures in terms of their compliance with the objectives system. It is implemented in several stages:

I. Development of a system of goals, which is a structural basis for the introduction of all types of activities of the enterprise, based on the final results, regardless of the distribution of structural subdivisions and program-target subsystems of the enterprise.

II. Expert analysis of the proposed variants of the organizational management structure in terms of ensuring the achievement of each goal.

III. Mapping rights and responsibilities for achieving goals for individual employees and entire units.

The method of organizational modeling is the development of formalized mathematical, graphic, machine and other reflections of the distribution of powers and responsibilities of employees, which is the basis for building, analyzing and evaluating various options of organizational management structures. Among organizational models it is necessary to allocate:

- Cybernetic models of hierarchical administrative structures describing organizational connections and relations in the form of systems of mathematical equations and inequalities or using machine simulation languages (multistage optimization models, models of system, «industrial» dynamics, etc.);

- Graph-analytical models of organizational structures of management, represent network, matrix and other tabular and graphic representations of the division of functions, powers, responsibilities, organizational relationships. They give an opportunity to analyze their orientation, causes, to 
evaluate various options for the grouping of interrelated activities in homogeneous units, to «lose» variants of distribution of rights and responsibilities between different levels of leadership, etc. («Metachemical» descriptions of the material, information, money flow1 together with management actions, the matrix of distribution of powers and responsibilities, the scheme of decision-making processes, the table of coefficients of relations between the functions of production and management etc.);

- Natural models of organizational structures and processes, which consist in assessing their functioning in real organizational conditions. These include organizational experiments - pre-planned and controlled restructuring of structures and processes in the business environment; laboratory experiments - artificial situation created by decision-making and organizational behavior, similar to real organizational conditions; management games - the actions of practical workers (game participants), based on pre-established rules for assessing their current;

- Mathematical and statistical models of dependencies between initial factors of formation of organizational structures of management and their characteristics. They are based on the collection, analysis and processing of empirical data on enterprises that operate in comparable conditions (models depending on the number of employees on the technical and economic characteristics of the enterprise, the dependence of indicators of specialization, centralization, standardization of management work on the goals and objectives of management, etc.).

The analysis of world models of municipal enterprises management makes it possible to conclude that in the foreign practice the following organizational structures of management of municipal enterprises of the city are used, which are based on the principles of improving the personnel management structure:

- An organizational structure that focuses on foresight. It can provide fast, independent and responsible actions of its employees only when an increasingly clear, far-reaching, practical foresight serves as a general basis for decision-making, to present to employees the purpose for which they can direct their efforts. This is accepted in the context of an organization where groups of workers are diverse in cultural relations. Achieving a common understanding between different groups of employees is one of the key functions of senior management.
- Integrated organizational structure with cross functions. The traditional functional structure covers such spheres as marketing, production, housing, communal services etc. This is an organizational structure of the matrix type, which involves the coordination of a number of functions.

- Simplified and authorized organizational structure. As the organizational structure becomes more simplified and less hierarchical, it empowers employees to assume greater responsibility and work more independently. The main advantage of this organizational structure is the attraction and responsibility of the employees, which leads to more rapid and full satisfaction of the needs of all categories of staff of the communal enterprise.

- Global organizational structure. The growth of production and technological capabilities, the universality of consumer and resource markets require a global organization of action. Thus, if the utility is associated with the implementation of export-import operations, then it should have a global strategy that will allow operations in a number of countries at any stage of the commodity exchange operation.

- Network organizational structure. In the process of providing housing and communal services to the population of the city there are situations for which the company requires business partners to resolve. Utility companies may conclude joint venture agreements or other agreements according to which certain functions are assigned to other enterprises or may be set up by economic associations.

- An organizational structure based on information technology. This organizational structure provides for widespread use of computer technology, information systems in the management of financial and business activities of the enterprise.

- Flexible, adaptive organizational structure. Adaptability of the organizational structure to changes in the markets and in its environment is ensured by targeted training of employees and the inclusion of self-analysis in the process of activity. In the training of staff, methods such as consistent experimentation and individual assessment of an employee's performance can be applied.

- Organizational structure, stimulated by consumers of housing and communal services. Proceeding from the fact that market orientation and satisfaction of the needs of consumers of housing and communal services are the key objectives of the enterprise, this organizational structure involves taking into account the views of clients when 
forming a production program, using methods of encouraging clients in the framework of measures to stimulate the offer of their services.

- Organizational structure oriented on profit and general quality. In this case, the company's orientation is foreseen in those areas where it has advantages in terms of service quality and, hence, the probability of obtaining the largest amount of profit.

- Organizational structure, the action of which is aimed at accelerating the process of providing services. This organizational structure envisages the orientation of the enterprise to increase the volume of service provision, strengthening the technical and technological capabilities of production, activating the efforts of the company to further promote services to the consumer.

Conclusions. Thus, there is a need to use world experience in order to choose the optimal model of management of municipal enterprises of the city, taking into account the improvement of the personnel management structure.

Improving the efficiency of utility companies is now closely linked to bringing them to European standards of resource consumption.

The main administrative method should not be administrative coercion, but stimulation, effective incentive to perform the tasks assigned to the communal enterprise by the territorial community. This can be done through a competent distribution of managerial functions, in which the activities of local self-government bodies focus on certain key aspects of a strategic nature, ensuring the rational freedom of action for managers of utilities.
Management of communal enterprises is carried out through the system of organizational and economic authority of territorial communities and local self-government bodies in relation to economic entities of the municipal sector of the economy. Local self-government bodies create and maintain communal property objects that guarantee the provision of services, participate in the establishment of industrial enterprises, regulate relations with consumers, and provide a system of information.

Therefore, for this purpose it is necessary to clearly present the goals, tasks and motives of behavior as representatives of local self-government bodies as representatives of the interests of the territorial community) and managers of communal enterprises.

In today's conditions of development of cities, the scientifically substantiated definition of management functions and quantity norms as a part of the overall process of forming the organizational and management structure of communal enterprises, the definition of the system of management goals that determine the structure and content of the functions of the management apparatus of municipal enterprises of the city, is important.

Therefore, today there is a need for a scientific substantiation of the need to improve the personnel management structure as the basis for the development of municipal enterprises in cities as a strategic imperative for the development of the Ukrainian city administration system.

\section{СПИСОК ЛІТЕРАТУРИ}

1. Господарський кодекс України від 16.01.2003 № 463. Офіційний вісник України. 2003. № 11. Ст. 462.

2. Монастирський Г.Л. Модернізаційна парадигма розвитку муніципальної економіки. Вісник Донецького національного університету. 2009. № 2. С. 44-52.

3. Заблодська I.В., Салуквадзе І.М., Андрійчук М.Д. Сучасні форми господарювання у житлово-комунальній сфері міста: монографія. Донецьк: Ноулідж, 2011. 192 с.

4. Запатрина І., Лебеда Т. Реформування житлово-комунального господарства в умовах макроекономічної нестабільності. Економіка України. 2011. № 10. С. 16-29.

5. Носков С. Государственно-частное партнерство в системе муниципального хозяйства Европы. Федерализм. 2005. № 2. C. 223-243.

6. Норекян М. Водоснабжение: государство и / или рынок. Энергия: экономика, техника, экология. 2007. № 7. С. 30 - 39.

7. Найден С.Н. Зарубежный опыт развития рыночных отношений в сфере жилищно-комунальних услуг. Экономика и управление. 2006. № 3 (24). С. 66-73.

8. Green Paper on public-private partnerships and Community law on public contracts and concessions. EU Publications. 2004. URL: https://publications.europa.eu/en/publication-detail/-/publication/94a3f02f-ab6a-47ed-b6b2-7de60830625e/language-en (дата звернення: 20.02.2018).

9. Государственное управление на современном этапе. Экономика и управление в зарубежных странах (по материалам иностранной печати). 2014. № 1. С. 3-9. 


\section{REFERENCES}

1. Hospodarskyi kodeks Ukrainy vid 16.01.2003 No. 463. Ofitsiinyi visnyk Ukrainy. 2003. No. 11. St. 462 [in Ukrainian].

2. Monastyrskyi H.L. Modernizatsiina paradyhma rozvytku munitsypalnoi ekonomiky. Visnyk Donetskoho natsionalnoho universytetu. 2009. No. 2: 44-52 [in Ukrainian].

3. Zablodska I.V., Salukvadze I.M., Andriichuk M.D. Suchasni formy hospodariuvannia u zhytlovo-komunalnii sferi mista: monohrafiia. Donetsk: Noulidzh, 2011 [in Ukrainian].

4. Zapatryna I., Lebeda T. Reformuvannia zhytlovo-komunalnoho hospodarstva v umovakh makroekonomichnoi nestabilnosti. Ekonomika Ukrainy. 2011. No. 10: 16-29 [in Ukrainian].

5. Noskov S. Gosudarstvenno-chastnoe partnerstvo v sisteme municipal'nogo hozjajstva Evropy. Federalizm. 2005. No. 2: 223-243 [in Russian].

6. Norekjan M. Vodosnabzhenie: gosudarstvo i/ili rynok. Jenergija:jekonomika, tehnika, jekologija. 2007. No. 7: 30-39 [in Russian].

7. Najden S.N. Zarubezhnyj opyt razvitija rynochnyh otnoshenij v sfere zhilishno-komunal'nih uslug. Jekonomika i upravlenie. 2006. No. 3(24): S. 66-73 [in Russian].

8. Green Paper on public-private partnerships and Community law on public contracts and concessions. EU Publications. 2004. URL: https://publications.europa.eu/en/publication-detail/-/publication/94a3f02f-ab6a-47ed-b6b2-7de60830625e/language-en

9. Gosudarstvennoe upravlenie na sovremennom jetape. Jekonomika i upravlenie v zarubezhnyh stranah (po materialam inostrannoj pechati). 2014. No. 1: 3-9 [in Russian].

Надійшла 05.03.2018

\section{Е.В. Тарасевич, Г.Г. Нестеров}

Институт экономико-правовых исследований НАН Украины, г. Киев, Украина

\section{УПРАВЛЕНИЕ КОММУНАЛЬНЫМИ ПРЕДПРИЯТИЯМИ ГОРОДА НА ОСНОВЕ СОВЕРШЕНСТВОВАНИЯ СТРУКТУРЫ УПРАВЛЕНИЯ ПЕРСОНАЛОМ}

Обоснованы основные направления совершенствования структуры управления персоналом коммунальных предприятий как стратегический императив развития городской системы управления. Проанализировано влияние совершенствования структуры управления персоналом на развитие системы управления муниципальными предприятиями города. Сделан вывод о необходимости повышения эффективности деятельности коммунальных предприятий с целью ее приведения в соответствие с европейскими стандартами на основе совершенствования структуры управления персоналом.

Ключевые слова: управление, персонал, коммунальные предприятия, организационная структура, территориальная громада.

\section{О.В. Тарасевич, Г.Г. Нєстєров}

Інститут економіко-правових досліджень НАН України, м. Київ, Україна

УПРАВЛІННЯ КОМУНАЛЬНИМИ ПІДПРИЕМСТВАМИ МІСТА НА ЗАСАДАХ УДОСКОНАЛЕННЯ СТРУКТУРИ УПРАВЛІННЯ ПЕРСОНАЛОМ

Обгрунтовано основні напрями удосконалення структури управління персоналом комунальних підприємств як стратегічного імперативу розвитку системи управління містом. Проаналізовано вплив удосконалення структури управління персоналом на розвиток системи управління комунальними підприємствами міста. Зроблено висновок щодо необхідності підвищення ефективності діяльності комунальних підприємств із метою увідповіднення їх європейським стандартам на основі удосконалення структури управління персоналом. Відзначено необхідність використання світового досвіду із метою вибору оптимальної моделі управління комунальними підприємствами міста 3 урахуванням удосконалення структури управління персоналом. Підкреслено, що підвищення ефективності діяльності комунальних підприємств тісно пов'язано з дотриманням ними європейських стандартів ресурсоспоживання.

Виявлено, шо управління комунальними підприємствами здійснюється за допомогою системи організаційногосподарських повноважень територіальних громад та органів місцевого самоврядування щодо суб'єктів господарювання комунального сектору економіки. Необхідно чітко уявляти цілі, завдання і мотиви поведінки як представників органів місцевого самоврядування як виразників інтересів територіальної громад, так і керівників комунальних підприємств.

Кінцевим критерієм ефективності для порівняння різних варіантів організаційних структур управління є найповніше й стійкіше досягнення цілей фінансово-господарської діяльності підприємства. Тому доцільно використання набору нормативних характеристик апарату управління: його продуктивність у переробці інформації, оперативність управлінських рішень, надійність апарату управління, що полягає у виконанні рішень у рамках установлених строків і ресурсів, адаптивність і гнучкість, що характеризується своєчаснім виявленням проблем і відповідною переорієнтацією роботи.

Нині необхідним є наукове обгрунтування удосконалення структури управління персоналом, основи розвитку комунальних підприємств міст як стратегічного імперативу розвитку системи управління містами України.

Ключові слова: управління, персонал, комунальні підприємства, організаційна структура, територіальна громада. 